\title{
Evaluation of F1 Hybrids/Genotypes of Pumpkin for Biochemical Traits
}

\author{
Vimlesh Kumar $^{1}$, D.P. Mishra ${ }^{1}$, G.C. Yadav ${ }^{1}$ and D.K. Dwivedi ${ }^{2}$ \\ ${ }^{1}$ Department of Vegetable Science, ${ }^{2}$ Department of P.M.B. \& G.E./GPB \\ N.D.U. A. \& T. Kumarganj, Faizabad-224229 (U.P.), India \\ *Corresponding author
}

\begin{tabular}{|c|c|}
\hline & A B S T R A C T \\
\hline & \multirow{4}{*}{$\begin{array}{l}\text { The investigations were conducted with the using of } 15 \mathrm{~F}_{1} \text { hybrids developed } \\
\text { through diallel excluding reciprocals with } 6 \text { parents of pumpkin. The germplasms } \\
\text { were evaluated for seven biochemical traits, viz., dry matter content, total soluble } \\
\text { solids, total sugars, reducing sugars, non-reducing sugars, ascorbic acid content } \\
\text { and } \beta \text {-carotene. The analysis of variance revealed wide range of variation among } \\
\text { genotypes for all the traits. On the basis of mean performance the hybrids namely, } \\
\mathrm{P}_{2} \times \mathrm{P}_{4} \text { and } \mathrm{P}_{3} \times \mathrm{P}_{5} \text { for dry matter content, } \mathrm{P}_{5} \times \mathrm{P}_{6} \text { and } \mathrm{P}_{1} \times \mathrm{P}_{5} \text { for total soluble solids, } \\
\mathrm{P}_{2} \times \mathrm{P}_{3} \text { and } \mathrm{P}_{1} \times \mathrm{P}_{4} \text { for total sugars }(\%), \mathrm{P}_{2} \times \mathrm{P}_{5} \text { and } \mathrm{P}_{3} \times \mathrm{P}_{5} \text { for reducing sugars }(\%) \text {, } \\
\mathrm{P}_{1} \times \mathrm{P}_{3} \text { and } \mathrm{P}_{2} \times \mathrm{P}_{3} \text { for non-reducing sugars }(\%), \mathrm{P}_{1} \times \mathrm{P}_{2} \text { and } \mathrm{P}_{4} \times \mathrm{P}_{6} \text { for ascorbic acid } \\
(\mathrm{mg} / 100 \mathrm{~g}) \text { and } \mathrm{P}_{2} \times \mathrm{P}_{6} \text { and } \mathrm{P}_{1} \times \mathrm{P}_{2} \text { for } \beta \text {-carotene were first and second ranker on } \\
\text { the basis of merit during pooled analysis respectively. The study concluded that } \\
\text { these hybrids can be exploited for cultivation. }\end{array}$} \\
\hline $\begin{array}{l}\text { Biochemical } \\
\text { traits, } \\
\text { Pumpkin, } \\
\text { F1 hybrids, } \\
\beta \text {-carotene. }\end{array}$ & \\
\hline Article Info & \\
\hline $\begin{array}{l}\text { Accepted: } \\
12 \text { April } 2017 \\
\text { Available Online: } \\
10 \text { May } 2017\end{array}$ & \\
\hline
\end{tabular}

\section{Introduction}

Pumpkin (Cucurbita moschata Duch. ex. Poir) is one of the most important vegetable crop of cucurbitacea family grown throughout the world not only for good sources of nutrition to the consumers but also for it $\mathrm{s}$ higher returns to the farmers. It is originated from central Maxico. Pumpkin is a herbaceous annual, sexually propagated vegetable having an identical genomic formula $2 n=2 x=40$. The word pumpkin originates from the word pepon, which is a Greek word meaning for "large melon", something round and large.

Cytogenetically, the species of Cucurbita show amazing uniformity in chromosome number and all the species have 20 pairs $(2 n=$
40) of small, dot like chromosomes (Whitaker and Robinson 1986) and isozyme studies indicate the allotetraploid origin of the genus (Weeden, 1984; Kirkpatrick et al., 1985). Based on commercial significance the cultivated Cucurbita species rank collectively among the 10 leading vegetable crops worldwide. China and India lead the world production. Other major producers are U.S., Egypt, Mexico, Ukraine, Cuba, Italy, Iran and Turkey (Ferriol and Pico, 2008). The total area of pumpkin in India is 19760 hectare whereas, the total production is 0.42 million tonne (Annonymous, 2015). Robinson and Decker-Walters (1999) concluded that in genus Cucurbita there are 5 cultivated and 10 wild species. Seshadri and More (2009) also 
stated that the recent recognition of synonyms and taxonomic changes have reduced the number of Cucurbita species to 15 or even less. The five cultivated species are $C$. Argyrosperma (earlier C. Mixta), C. pepo, C. maxima, C. moschata and C. ficifolia.

In India, pumpkin and squashes were introduced from South America by foreign navigators and emissaries. Cucurbita moschata is more widely cultivated than other four cultivated species in our country. Since Cucurbita moschata is amenable to hotter climates more than other cultivated species, it is also the most widely grown throughout the tropics of both hemispheres. Pumpkins, like other squash, are thought to have originated in North America.

The oldest evidence, pumpkin-related seeds dating between 7000 and 5500 BC, were found in Mexico. The color of pumpkins is derived from the orange pigments abundant in them. The main nutrients are lutein and both alpha and beta carotene, the latter of which generates vitamin $\mathrm{A}$ in the body. Pumpkins are very versatile in their uses for cooking. Most parts of the pumpkin are edible, including the fleshy shell, the seeds, the leaves, and even the flowers. In the United States and Canada, pumpkin is a popular Halloween and Thanksgiving staple. Pumpkin purée is sometimes prepared and frozen for later use.

Pumpkin is relatively high in energy and carbohydrates and a good source of vitamins, especially high caretenoid pigments and minerals. It may certainly contribute to improve nutritional status of the people, particularly the vulnerable groups in respect of vitamin A requirement. Night-blindness is a serious problem of South Asian countries. Encouraging the mass people to take more pumpkin can easily be solved the problem.

\section{Materials and Methods}

The experiments were conducted in Randomized Block Design (RBD) with three replications to assess the performance of 15 $\mathrm{F}_{1}$ hybrids and 6 parents in two seasons (Kharif and Rabi 2015-16). The treatments were planted in rows spaced at 3.0 meters apart with a plant to plant spacing of 0.6 meter. The experiments were sown on $23^{\text {th }}$ July, 2015 and $7^{\text {th }}$ November 2015 for Kharif and Rabi crops respectively. All the recommended agronomic package of practices and protection measures were followed to raise good crop. Three experiments were conducted during Kharif $\left(\mathrm{E}_{1}\right)$, Rabi seasons $\left(\mathrm{E}_{2}\right)$ and summer season $\left(E_{3}\right)$ of 2015-16 at Main Experiment Station of Department of Vegetable Science, at Narendra Deva University of Agriculture \& Technology, Narendra Nagar (Kumarganj), Faizabad (U.P.).

\section{Biochemical Traits}

\section{Ascorbic acid (mg/100 g fresh fruit)}

Ascorbic acid content was estimated by crushing $10 \mathrm{~g}$ fresh fruit with three per cent metaphosphoric acid as buffer. The extract was filtered and $100 \mathrm{ml}$ volume was made with three per cent $\mathrm{HPO}_{3} .10 \mathrm{ml}$ aliquot was titrated against, 2,6-dichlorophenolindophenol dye solution till the light pink colour appeared. The results were expressed as $\mathrm{mg} / 100 \mathrm{~g}$ of fresh fruit (A.O.A.C., 1970).

\footnotetext{
Ascorbic acid $(\mathrm{mg} / 100 \mathrm{~g})=\frac{\text { Titrated value }(\mathrm{ml}) \times \text { Dye factor } \mathrm{x} \text { Vol. made up }(\mathrm{ml})}{\text { Aliquot of extract ta } \mathrm{ken}(\mathrm{ml}) \times \text { Weight of sample taken for estimation }(\mathrm{g})} \times 100$
} 


\section{Reducing sugars (\%)}

Reducing sugars were estimated by Fehling ' $A$ ' and 'B' solution method given by Ranganna (1991). $10 \mathrm{~g}$ fresh fruit was macerated in the small amount of distilled water and filtered through muslin cloth and maintain volume up to $100 \mathrm{ml}$. An aliquot of $5 \mathrm{ml}$ diluted fruit juice was taken from $100 \mathrm{ml}$ as above for titration and mixed with $10 \mathrm{ml}$ of Fehling ' $A$ ' and ' $B$ ' solution each. This mixture was titrated against $1.0 \%$ glucose. A blank with $10 \mathrm{ml}$ of Fehling 'A' and 'B' was also run. The results were expressed as per cent reducing sugars.

Total invert sugar, out of $100 \mathrm{ml}$ sample, $5 \mathrm{ml}$ aliquot was taken, mixed with three drops of $\mathrm{HCl}$ and kept overnight. Next day 2-3 drops of phenolphthalein indicator was added and neutralized with 30 per cent sodium hydroxide $(\mathrm{NaOH})$ solution containing $10 \mathrm{ml}$ Fehling ' $A$ ' and ' $B$ '. This mixture was titrated against $1.0 \%$ glucose in boiling solution using methylene blue indicator. The appearance of red or black colour was marked as the end point. The results were expressed as per cent total invert sugars.

\section{Non-reducing sugars (\%)}

Non-reducing sugars was calculated by deducting the quantity of reducing sugars from total invert sugars and multiplied by factor 0.95 . The results were expressed as per cent non-reducing sugars.

\section{Total sugars $(\%)$}

Total sugars were calculated by adding the quantity of reducing and non-reducing sugars. The results were expressed as total sugars in per cent.

Total sugars $(\%)=$

Reducing sugars $(\%)+$ Non - reducing sugars $(\%)$

\section{Dry matter content in fruit}

The dry matter content in fruit was determined on the fresh weight basis. A quantity of $100 \mathrm{~g}$ of fresh fruit was taken, cut into small pieces and allowed for sun drying and then dried in oven at $60 \pm 2{ }^{\circ} \mathrm{C}$ for $8-10$ hours per day till the complete drying to have constant weight and dry matter percentage was calculated as:

Dry matter $(\%)=\frac{\text { Dry matter of fruit }(\mathrm{g})}{\text { Fresh weig ht of fruit }(\mathrm{g})} \times 100$

\section{Total soluble solids $\left({ }^{\circ} \mathbf{B}\right)$}

Total soluble solids of the juice of fresh fruit of each strains/lines $/ \mathrm{F}_{1}$ 's were determined with the help of hand refractometer (Erma, Japan) of 0-32 per cent range. The values were collected at $20^{\circ} \mathrm{C}$ and expressed as per cent TSS of fresh fruit juice.

\section{Carotene (mg/100g)}

The $\beta$ - carotene content was determined in mature fruit sample using the method develoed by Rangana (1997). Five gram fresh fruit sample were cut into small pieces and homogenized with the help of pestle and mortar by adding $10 \mathrm{ml}$ acetone. The acetone extracted material was transferred into seperatory funnel and 10-15 ml petroleum ether was added and mixed gently. There were two layers formed in the seperatory funnel. Upper layer or ether layer (pigmented layer) was collected while lower layer was discarded. Repeat the extraction process of acetone phase (upper layer) until it was colourless. Ether phase was transferred into $250 \mathrm{ml}$ conical flasks and volume was made up $100 \mathrm{ml}$ by adding petroleum ether. $5 \mathrm{~g}$ of anhydrous sodium sulphate was added in conical flask. Finally the intensity of the color was measured at 452 and $503 \mathrm{~nm}$ on spectronic 20 against blanck reagent and 
results were expressed as $\mathrm{mg} / 100 \mathrm{~g}$ sample. The calculation was done by using following formula.

B- Carotene content $(\mathrm{mg} / 100 \mathrm{~g})=$ $13.9 \times 100 \times$ O.D. at $452 \mathrm{~nm} \times 1000$

Wt. of sample $\times$ O.D. at $503 \mathrm{~nm} \times 1000$

\section{Statistical analysis}

The average values for each genotype in each replication for the traits studied were used for further statistical analysis. A brief outline of the procedure adopted for the estimation of statistical parameters. Analysis of variance, the data for the component traits was analysed as per the following model given by Panse and Sukhatme (1984). The calculated ' $F$ ' values were compared with the tabulated ' $F$ ' values at $5 \%$ level of significance. If the calculated ' $F$ ' value was higher than the tabulated, it was considered to be significant.

\section{Results and Discussion}

The perusal of (Table 1) that the dry matter content was varied from $5.33 \%$ to $8.68 \%$ in $\mathrm{E}_{1}, 5.03$ to $8.74 \%$ in $\mathrm{E}_{2}, 5.56$ to $9.00 \%$ in $\mathrm{E}_{3}$ and 5.34 to $8.01 \%$ in pooled. $\mathrm{F}_{1}$ hybrid, $\mathrm{P}_{3}$ $\times \mathrm{P}_{5}$ produced highest dry matter content in $E_{1}$ and $E_{3}$ which was significantly superior to rest of the hybrids/ parents except $\mathrm{P}_{2}$, hybrid $\mathrm{P}_{5} \times \mathrm{P}_{6}$ produced highest dry matter content in $\mathrm{E}_{2}, \quad \mathrm{P}_{2} \times \mathrm{P}_{4}$ followed by $\mathrm{P}_{3} \times \mathrm{P}_{5}$ produced maximum dry matter content in over seasons (pooled). Total soluble solids ranged from 4.14 to $7.23{ }^{\circ}$ Brix in $\mathrm{E}_{1}, 4.47$ to $7.59{ }^{\circ}$ Brix in $\mathrm{E}_{2}, 4.53$ to $7.63{ }^{\circ}$ Brix in $\mathrm{E}_{3}$ and 4.64 to 6.75 ${ }^{\circ}$ Brix in pooled. The highest total soluble solids was recorded in $\mathrm{P}_{3} \times \mathrm{P}_{5}$ which is significantly superior to rest of the hybrids/ parents except $\mathrm{P}_{3} \times \mathrm{P}_{4}$ in $\mathrm{E}_{1}$ and $\mathrm{E}_{3}$, while, hybrid $\mathrm{P}_{5} \times \mathrm{P}_{6}$ recorded maximum total soluble solids in $\mathrm{E}_{2}$ and over seasons. Total sugars varied from 3.38 to $6.56 \%$ in $\mathrm{E}_{1}, 3.44$ to 6.56 $\%$ in $\mathrm{E}_{2}, 3.63$ to $6.02 \%$ in $\mathrm{E}_{3}$ and 4.17 to 5.91 in pooled. Hybrid $\mathrm{P}_{2} \times \mathrm{P}_{3}$ recorded maximum total sugars followed by $\mathrm{P}_{3} \times \mathrm{P}_{5}, \mathrm{P}_{3} \times \mathrm{P}_{4}$ and $\mathrm{P}_{1} \times \mathrm{P}_{6}$ in $\mathrm{E}_{1}$, hybrid $\mathrm{P}_{5} \times \mathrm{P}_{6}$ followed by $\mathrm{P}_{1} \times \mathrm{P}_{5}$ and $\mathrm{P}_{2} \times \mathrm{P}_{3}$ in $\mathrm{E}_{2}$ while, hybrid $\mathrm{P}_{2} \times \mathrm{P}_{3}$ had maximum total sugar content in $\mathrm{E}_{3}$ and pooled significant differences among genotypes was observed for this trait. Reducing sugars ranged from 1.77 to $3.85 \%$ in $\mathrm{E}_{1}, 2.34$ to 4.47 $\%$ in $\mathrm{E}_{2}, 2.02$ to $4.10 \%$ in $\mathrm{E}_{3}$ and 2.33 to 3.66 $\%$ in pooled. The maximum reducing sugars was recorded in hybrid $\mathrm{P}_{3} \times \mathrm{P}_{4}$ followed by $\mathrm{P}_{3} \times \mathrm{P}_{5}, \mathrm{P}_{1} \times \mathrm{P}_{2}$ and $\mathrm{P}_{2} \times \mathrm{P}_{3}$ during $\mathrm{E}_{1}$, hybrid $\mathrm{P}_{5} \times \mathrm{P}_{6}$ had maximum reducing sugars which was significantly superior to rest of hybrids/parents during $\mathrm{E}_{2}$ while, during $\mathrm{E}_{3}$ and over seasons maximum reducing sugars recorded in $\mathrm{P}_{2} \times \mathrm{P}_{5}$ followed by $\mathrm{P}_{3} \times \mathrm{P}_{5}$ and $\mathrm{P}_{2} \times \mathrm{P}_{3}$. Non-reducing sugars ranged from 1.50 to $2.90 \%$ in $\mathrm{E}_{1}, 1.10$ to $2.64 \%$ in $\mathrm{E}_{2}, 1.37$ to $2.94 \%$ in $\mathrm{E}_{3} 1.52$ to $2.37 \%$ over seasons. Hybrid $\mathrm{P}_{1} \times \mathrm{P}_{6}$ followed by $\mathrm{P}_{3}, \mathrm{P}_{1} \times \mathrm{P}_{4}$ and $\mathrm{P}_{6}$ had maximum non-reducing sugars in $\mathrm{E}_{1}$, hybrid $\mathrm{P}_{1} \times \mathrm{P}_{2}$ had maximum non-reducing sugars, which was significantly superior to rest of the hybrids/ parents during $\mathrm{E}_{2}$. During $\mathrm{E}_{3}$ the maximum non-reducing sugars was recorded in hybrid $\mathrm{P}_{1} \times \mathrm{P}_{3}$ which was significantly superior to rest of the hybrids/ parents. Hybrid, $\mathrm{P}_{1} \times \mathrm{P}_{4}$ followed by $\mathrm{P}_{1} \times \mathrm{P}_{3}$, $\mathrm{P}_{2} \times \mathrm{P}_{3}$ and $\mathrm{P}_{3}$ recorded maximum nonreducing sugars in over seasons. Ascorbic acid content varied from 4.72 to 8.45 $\mathrm{mg} / 100 \mathrm{~g}$ in $\mathrm{E}_{1}, 4.63$ to $9.34 \mathrm{mg} / 100 \mathrm{~g}$ in $\mathrm{E}_{2}$, 4.87 to $8.60 \mathrm{mg} / 100 \mathrm{~g}$ in $\mathrm{E}_{3}$ and 5.01 to 8.33 $\mathrm{mg} / 100 \mathrm{~g}$ over seasons. 
Table.1 Mean performance of genotypes (F1 hybrids and parents) in relation to biochemical traits during three seasons (E1, E2, E3) and pooled

\begin{tabular}{|c|c|c|c|c|c|c|c|c|c|c|c|c|c|c|c|c|c|}
\hline \multirow{2}{*}{\multicolumn{2}{|c|}{ Genotypes }} & \multicolumn{4}{|c|}{ Dry matter content (\%) } & \multicolumn{4}{|c|}{ Total soluble solids } & \multicolumn{4}{|c|}{ Total sugars (\%) } & \multicolumn{4}{|c|}{ Reducing sugars (\%) } \\
\hline & & $\mathbf{E}_{1}$ & $\mathbf{E}_{2}$ & $\mathbf{E}_{3}$ & Pooled & $\mathbf{E}_{1}$ & $\mathbf{E}_{2}$ & $\mathbf{E}_{3}$ & Pooled & $\mathbf{E}_{1}$ & $\mathbf{E}_{2}$ & $\mathbf{E}_{3}$ & Pooled & $\mathbf{E}_{1}$ & $\mathbf{E}_{2}$ & $\mathbf{E}_{3}$ & Pooled \\
\hline \multicolumn{2}{|l|}{$\mathbf{P}_{1} \times \mathbf{P}_{2}$} & 7.04 & 7.70 & 7.36 & 7.37 & 6.17 & 6.70 & 6.56 & 6.48 & 5.22 & 5.57 & 5.47 & 5.42 & 3.20 & 2.93 & 3.45 & 3.19 \\
\hline \multicolumn{2}{|l|}{$\mathbf{P}_{1} \times \mathbf{P}_{3}$} & 7.58 & 7.90 & 7.96 & 7.81 & 6.12 & 7.00 & 6.28 & 6.46 & 4.29 & 5.87 & 5.75 & 5.30 & 2.20 & 3.96 & 2.85 & 3.00 \\
\hline \multicolumn{2}{|l|}{$\mathbf{P}_{1} \times \mathbf{P}_{4}$} & 6.56 & 8.00 & 6.88 & 7.14 & 5.75 & 7.00 & 6.14 & 6.30 & 5.43 & 5.87 & 5.68 & 5.66 & 2.85 & 3.93 & 3.10 & 3.29 \\
\hline \multicolumn{2}{|l|}{$\mathbf{P}_{1} \times \mathbf{P}_{5}$} & 6.62 & 8.33 & 6.94 & 7.30 & 6.40 & 7.07 & 6.79 & 6.75 & 4.71 & 5.97 & 4.96 & 5.21 & 2.83 & 4.06 & 3.08 & 3.32 \\
\hline \multicolumn{2}{|l|}{$\mathbf{P}_{1} \times \mathbf{P}_{6}$} & 7.64 & 5.95 & 7.90 & 7.16 & 5.88 & 5.04 & 6.51 & 5.81 & 5.50 & 4.01 & 4.54 & 4.68 & 2.60 & 2.77 & 2.45 & 2.61 \\
\hline \multicolumn{2}{|l|}{$\mathbf{P}_{2} \times \mathbf{P}_{3}$} & 7.05 & 7.97 & 7.37 & 7.46 & 6.13 & 6.97 & 6.53 & 6.54 & 5.77 & 5.94 & 6.02 & 5.91 & 3.17 & 4.04 & 3.42 & 3.54 \\
\hline \multicolumn{2}{|l|}{$\mathbf{P}_{2} \times \mathbf{P}_{4}$} & 8.05 & 7.62 & 8.37 & 8.01 & 6.17 & 6.43 & 6.56 & 6.39 & 4.15 & 5.40 & 4.40 & 4.65 & 2.20 & 3.67 & 2.45 & 2.77 \\
\hline \multicolumn{2}{|l|}{$\mathbf{P}_{2} \times \mathbf{P}_{5}$} & 7.11 & 7.79 & 7.87 & 7.59 & 6.23 & 6.49 & 7.14 & 6.62 & 5.06 & 5.46 & 5.85 & 5.46 & 3.17 & 3.71 & 4.10 & 3.66 \\
\hline \multicolumn{2}{|l|}{$\mathbf{P}_{2} \times \mathbf{P}_{6}$} & 7.73 & 7.78 & 8.05 & 7.86 & 6.18 & 6.48 & 6.58 & 6.41 & 4.47 & 5.45 & 4.72 & 4.88 & 3.10 & 3.71 & 3.35 & 3.39 \\
\hline \multicolumn{2}{|l|}{$\mathbf{P}_{3} \times \mathbf{P}_{4}$} & 7.55 & 6.37 & 7.43 & 7.12 & 6.75 & 5.44 & 6.63 & 6.27 & 5.60 & 4.41 & 5.31 & 5.11 & 3.85 & 3.00 & 3.42 & 3.42 \\
\hline \multicolumn{2}{|l|}{$\mathbf{P}_{3} \times \mathbf{P}_{5}$} & 8.68 & 6.17 & 9.00 & 7.95 & 7.23 & 5.07 & 7.63 & 6.64 & 5.70 & 4.04 & 5.95 & 5.23 & 3.83 & 2.75 & 4.08 & 3.56 \\
\hline \multicolumn{2}{|l|}{$\mathbf{P}_{3} \times \mathbf{P}_{6}$} & 7.55 & 6.17 & 7.87 & 7.20 & 6.03 & 5.27 & 6.43 & 5.91 & 4.46 & 4.27 & 4.71 & 4.48 & 2.58 & 2.90 & 2.83 & 2.77 \\
\hline \multicolumn{2}{|l|}{$\mathbf{P}_{4} \times \mathbf{P}_{5}$} & 6.23 & 7.10 & 7.15 & 6.83 & 5.65 & 6.12 & 7.00 & 6.26 & 3.38 & 5.09 & 4.74 & 4.40 & 1.77 & 3.46 & 2.65 & 2.62 \\
\hline \multicolumn{2}{|l|}{$\mathbf{P}_{4} \times \mathbf{P}_{6}$} & 6.43 & 7.77 & 6.75 & 6.98 & 6.40 & 6.87 & 6.79 & 6.69 & 3.66 & 5.84 & 3.91 & 4.47 & 2.17 & 3.98 & 2.42 & 2.85 \\
\hline \multicolumn{2}{|l|}{$\mathbf{P}_{5} \times \mathbf{P}_{6}$} & 6.83 & 8.74 & 6.55 & 7.38 & 6.61 & 7.59 & 6.04 & 6.75 & 4.49 & 6.56 & 3.63 & 4.89 & 2.40 & 4.47 & 2.02 & 2.96 \\
\hline \multicolumn{2}{|l|}{$\mathbf{P}_{1}$} & 5.71 & 6.70 & 6.03 & 6.15 & 5.60 & 5.58 & 5.99 & 5.73 & 4.44 & 4.55 & 4.69 & 4.56 & 2.48 & 2.39 & 2.73 & 2.54 \\
\hline \multicolumn{2}{|l|}{$\mathbf{P}_{2}$} & 8.18 & 6.62 & 8.50 & 7.77 & 4.14 & 5.25 & 4.53 & 4.64 & 4.22 & 4.22 & 4.47 & 4.30 & 2.62 & 2.87 & 2.87 & 2.78 \\
\hline \multicolumn{2}{|l|}{$\mathbf{P}_{3}$} & 7.19 & 6.48 & 7.51 & 7.06 & 4.43 & 5.22 & 4.83 & 4.83 & 4.88 & 4.19 & 5.13 & 4.73 & 2.17 & 2.84 & 2.42 & 2.48 \\
\hline \multicolumn{2}{|l|}{$\mathbf{P}_{4}$} & 6.27 & 6.12 & 6.59 & 6.32 & 5.02 & 5.22 & 5.41 & 5.21 & 4.03 & 4.19 & 4.28 & 4.17 & 2.02 & 2.71 & 2.27 & 2.33 \\
\hline \multicolumn{2}{|l|}{$P_{5}$} & 5.33 & 5.03 & 5.65 & 5.34 & 5.02 & 4.47 & 5.41 & 4.96 & 4.67 & 3.44 & 4.92 & 4.34 & 2.23 & 2.34 & 2.48 & 2.35 \\
\hline \multicolumn{2}{|l|}{$\mathbf{P}_{6}$} & 6.07 & 5.56 & 6.39 & 6.00 & 5.07 & 4.68 & 5.46 & 5.07 & 5.25 & 3.65 & 5.50 & 4.80 & 2.77 & 2.48 & 3.02 & 2.76 \\
\hline Mean & & 7.02 & 7.04 & 7.34 & 7.13 & 5.86 & 6.00 & 6.25 & 6.03 & 4.73 & 4.95 & 4.98 & 4.89 & 2.68 & 3.28 & 2.93 & 2.96 \\
\hline S.E. $\pm N$ & & 0.18 & 0.12 & 0.20 & 0.22 & 0.17 & 0.12 & 0.20 & 0.18 & 0.19 & 0.13 & 0.19 & 0.22 & 0.16 & 0.09 & 0.16 & 0.16 \\
\hline C.D. 5 & & 0.52 & 0.33 & 0.57 & 0.62 & 0.48 & 0.35 & 0.58 & 0.50 & 0.53 & 0.36 & 0.53 & 0.62 & 0.45 & 0.24 & 0.45 & 0.46 \\
\hline Range & Lowest & 5.33 & 5.03 & 5.65 & 5.34 & 4.14 & 4.47 & 4.53 & 4.64 & 3.38 & 3.44 & 3.63 & 4.17 & 1.77 & 2.34 & 2.02 & 2.33 \\
\hline & Highest & 8.68 & 8.74 & 9.00 & 8.01 & 7.23 & 7.59 & 7.63 & 6.75 & 5.77 & 6.56 & 6.02 & 5.91 & 3.85 & 4.47 & 4.10 & 3.66 \\
\hline
\end{tabular}


Table 1. contd....

\begin{tabular}{|c|c|c|c|c|c|c|c|c|c|c|c|c|c|}
\hline \multirow{2}{*}{\multicolumn{2}{|c|}{ Genotypes }} & \multicolumn{4}{|c|}{ Non-reducing sugars (\%) } & \multicolumn{4}{|c|}{ Ascorbic acid (mg/100g) } & \multicolumn{4}{|c|}{ B-carotene (mg /100g) } \\
\hline & & $\mathbf{E}_{1}$ & $\mathbf{E}_{2}$ & $\mathbf{E}_{3}$ & Pooled & $\mathbf{E}_{1}$ & $\mathbf{E}_{2}$ & $\mathbf{E}_{3}$ & Pooled & $\mathbf{E}_{1}$ & $\mathbf{E}_{2}$ & $\mathbf{E}_{3}$ & Pooled \\
\hline \multicolumn{2}{|l|}{$\mathbf{P}_{1} \times \mathbf{P}_{2}$} & 1.95 & 2.64 & $\begin{array}{r}2.02 \\
\end{array}$ & 2.20 & 7.98 & \begin{tabular}{|r|}
8.87 \\
\end{tabular} & 8.14 & 8.33 & 6.88 & 7.23 & 7.24 & 7.12 \\
\hline \multicolumn{2}{|l|}{$\mathbf{P}_{1} \times \mathbf{P}_{3}$} & 2.09 & 1.91 & 2.90 & 2.30 & 4.98 & 7.82 & 7.69 & 6.83 & 6.10 & 5.47 & 5.48 & 5.68 \\
\hline \multicolumn{2}{|l|}{$\mathbf{P}_{1} \times \mathbf{P}_{4}$} & 2.58 & 1.94 & 2.58 & 2.37 & 6.52 & 8.68 & 6.67 & 7.29 & 4.03 & 4.38 & 4.39 & 4.27 \\
\hline \multicolumn{2}{|l|}{$\mathbf{P}_{1} \times \mathbf{P}_{5}$} & 1.87 & 1.91 & 1.88 & 1.89 & 5.52 & 7.83 & 5.67 & 6.34 & 3.57 & 7.40 & 3.93 & 4.96 \\
\hline \multicolumn{2}{|l|}{$\mathbf{P}_{1} \times \mathbf{P}_{6}$} & 2.90 & 1.34 & 2.09 & 2.11 & 7.54 & 7.14 & 5.14 & 6.61 & 5.12 & 6.49 & 6.46 & 6.02 \\
\hline \multicolumn{2}{|l|}{$\mathbf{P}_{2} \times \mathbf{P}_{3}$} & 2.30 & 1.90 & 2.60 & 2.27 & 6.93 & 7.21 & 7.09 & 7.08 & 5.36 & 5.75 & 5.72 & 5.61 \\
\hline \multicolumn{2}{|l|}{$\mathbf{P}_{2} \times \mathbf{P}_{4}$} & 1.96 & 1.73 & 1.95 & 1.88 & 6.72 & 8.91 & 6.87 & 7.50 & 4.14 & 4.53 & 4.50 & 4.39 \\
\hline \multicolumn{2}{|l|}{$\mathbf{P}_{2} \times \mathbf{P}_{5}$} & 1.91 & 1.75 & 1.75 & 1.80 & 4.73 & 9.34 & 7.73 & 7.27 & 6.78 & 4.13 & 4.11 & 5.01 \\
\hline \multicolumn{2}{|l|}{$\mathbf{P}_{2} \times \mathbf{P}_{6}$} & 1.52 & 1.75 & 1.37 & 1.55 & 5.72 & 6.05 & 5.87 & 5.88 & 7.80 & 8.18 & 8.16 & 8.05 \\
\hline \multicolumn{2}{|l|}{$\mathbf{P}_{3} \times \mathbf{P}_{4}$} & 1.73 & 1.41 & 1.89 & 1.68 & 7.58 & 5.20 & 4.89 & 5.89 & 3.75 & 6.99 & 7.14 & 5.96 \\
\hline \multicolumn{2}{|l|}{$\mathbf{P}_{3} \times \mathbf{P}_{5}$} & 1.88 & 1.29 & 1.86 & 1.68 & 5.02 & 7.08 & 5.17 & 5.76 & 4.31 & 4.70 & 4.67 & 4.56 \\
\hline \multicolumn{2}{|l|}{$\mathbf{P}_{3} \times \mathbf{P}_{6}$} & 1.88 & 1.37 & 1.88 & 1.71 & 6.05 & 6.89 & 6.20 & 6.38 & 3.33 & 3.82 & 3.69 & 3.62 \\
\hline \multicolumn{2}{|l|}{$\mathbf{P}_{4} \times \mathbf{P}_{5}$} & 1.61 & 1.63 & 2.09 & 1.78 & 7.16 & 8.19 & 6.34 & 7.23 & 5.95 & 5.41 & 5.39 & 5.58 \\
\hline \multicolumn{2}{|l|}{$\mathbf{P}_{4} \times \mathbf{P}_{6}$} & 1.50 & 1.86 & 1.50 & 1.62 & 8.45 & 6.70 & 8.60 & 7.92 & 6.20 & 6.59 & 6.56 & 6.45 \\
\hline \multicolumn{2}{|l|}{$\mathbf{P}_{5} \times \mathbf{P}_{6}$} & 2.39 & 2.09 & 1.61 & 2.03 & 6.18 & 6.48 & 7.31 & 6.66 & 5.03 & 7.31 & 6.31 & 6.22 \\
\hline \multicolumn{2}{|l|}{$\mathbf{P}_{1}$} & 1.95 & 2.16 & 1.95 & 2.02 & 6.11 & 5.74 & 6.22 & 4.63 & 6.13 & 6.38 & 6.49 & 6.34 \\
\hline \multicolumn{2}{|l|}{$\mathbf{P}_{2}$} & 1.60 & 1.35 & 1.60 & 1.52 & 6.38 & 5.13 & 6.54 & 6.02 & 5.92 & 6.17 & 6.28 & 6.12 \\
\hline \multicolumn{2}{|l|}{$\mathbf{P}_{3}$} & 2.71 & 1.33 & 2.71 & 2.25 & 5.38 & 4.85 & 5.53 & 5.25 & 5.00 & 5.25 & 5.36 & 5.20 \\
\hline \multicolumn{2}{|l|}{$\mathbf{P}_{4}$} & 2.01 & 1.47 & 2.01 & 1.83 & 4.72 & 5.44 & 4.87 & 5.01 & 4.28 & 4.61 & 4.64 & 4.51 \\
\hline \multicolumn{2}{|l|}{$\mathbf{P}_{5}$} & 2.45 & 1.10 & 2.45 & 2.00 & 5.83 & 4.63 & 5.98 & 5.48 & 3.22 & 3.58 & 3.58 & 3.46 \\
\hline \multicolumn{2}{|l|}{$\mathbf{P}_{6}$} & 2.48 & 1.17 & 2.48 & 2.05 & 5.08 & 5.84 & 5.23 & 5.38 & 4.17 & 5.23 & 4.53 & 4.64 \\
\hline \multicolumn{2}{|c|}{ Mean } & 2.06 & 1.67 & 2.06 & 1.93 & 6.22 & 6.86 & 6.37 & 6.48 & 5.10 & 5.70 & 5.46 & 5.42 \\
\hline \multicolumn{2}{|c|}{ S.E. $\pm M$} & 0.12 & 0.05 & 0.14 & 0.12 & 0.13 & 0.13 & 0.17 & 0.30 & 0.13 & 0.13 & 0.13 & 0.23 \\
\hline \multicolumn{2}{|c|}{ C.D. 5\% } & 0.36 & 0.15 & 0.40 & 0.34 & 0.36 & 0.37 & 0.49 & 0.83 & 0.36 & 0.37 & 0.36 & 0.64 \\
\hline Range & Lowest & 1.50 & 1.10 & 1.37 & 1.52 & 4.72 & 4.63 & 4.87 & 5.01 & 3.22 & 3.58 & 3.58 & 3.46 \\
\hline & Highest & 2.90 & 2.64 & 2.94 & 2.37 & 8.45 & 9.34 & 8.60 & 8.33 & 7.80 & 8.18 & 8.16 & 8.05 \\
\hline
\end{tabular}


Hybrid $\mathrm{P}_{4} \times \mathrm{P}_{6}$ followed by $\mathrm{P}_{1} \times \mathrm{P}_{2}, \mathrm{P}_{3} \times \mathrm{P}_{4}$ and $\mathrm{P}_{1} \times \mathrm{P}_{6}$ recorded maximum ascorbic acid content during $\mathrm{E}_{1}$, hybrid $\mathrm{P}_{2} \times \mathrm{P}_{5}$ had maximum ascorbic acid which was significantly superior to rest of hybrids/parents during $\mathrm{E}_{2}$, during $\mathrm{E}_{3}$ hybrids viz., $\mathrm{P}_{4} \times \mathrm{P}_{6}$ followed by $\mathrm{P}_{1} \times \mathrm{P}_{2}, \mathrm{P}_{2} \times \mathrm{P}_{5}, \mathrm{P}_{1} \times \mathrm{P}_{3}$ and $\mathrm{P}_{5} \times \mathrm{P}_{6}$ recorded maximum ascorbic acid while, in pooled analysis hybrid $\mathrm{P}_{1} \times \mathrm{P}_{2}$ it was significantly superior to rest of hybrids/parents. $\beta$-carotene ranged from 3.22 to $7.80 \mathrm{mg} / 100 \mathrm{~g}$ in $\mathrm{E}_{1}, 3.58$ to $8.18 \mathrm{mg} / 100 \mathrm{~g}$ in $\mathrm{E}_{2}, 3.58$ to $8.16 \mathrm{mg} / 100 \mathrm{~g}$ in $\mathrm{E}_{3}$ and 3.46 to $8.05 \mathrm{mg} / 100 \mathrm{~g} . \mathrm{P}_{2} \times \mathrm{P}_{6}$ was recorded maximum $\beta$-carotene during all three seasons $\left(E_{1}, E_{2}\right.$, $E_{3}$ ) and over seasons significant differences among genotypes were observed for this trait. The results are in agreement with the findings of Tian ChengRui et al., (1999); Gwanama et al., (2002); Pandey et al., (2002); Carvalho et al.,(2012); Selvi et al., (2012); Zinash et al., (2013) and Sharma and Ramana (2013).

\section{References}

A.O.A.C. 1970. Official Methods of Analysis. $12^{\text {th }}$ Ed. Association of Official analysis Chemist, Washington, D.C.

Anonymous. 2015. Indian Horticulture Database. National Horticulture Board, Ministry of Agriculture, Government of India, Gurgaon.

Ferriol and Pico. 2008. 'Pumpkin and Winter Squash' A Book Chapter in Vegetable I pp. 317-349. Edited by Jaime Prohens and Fernando Nuez Springer Science + Business Media.

Gwanama, C., Nichterlein, K., Lungu, D. and Simabwachi, W. 2002. Variation of fruit beta-carotene content of tropical pumpkin [Cucurbita moschata (Duchsne) Piorot] land races in Zambia. Pl. Genet. Res. Newslett., 129: 44-46.

Kirkpatrick, K.J., Decker, D.S., Wilson, H.W. 1985. Allozyme differentiation in the $C$. pepo complex: C. pepo var. medullosa vs. C. texana. Economic Bot., 39: 289299.

Pandey, S., Singh, J., Upadhyay, A.K. and Ram, D. 2002. Genetic variability for antioxidants and yield components in pumpkin (Cucurbita moschata Duch. ex poir. Veg. Sci., 29: 123-126.

Panse, V.G. and Shukhatme, P.V. 1984. Statistical Methods for Agricultural Workers, $2^{\text {nd }}$ eds. Indian Council of Agriculture Research, New Delhi. pp. 235-247.

Ranganna, S.C. 1991. Handbook of Analysis and Quality Control of Fruit and Vegetable Products. Tata Mc Graw Hill Publishing Co., Calcutta. pp. 279-309.

Ranganna, S.C. 1997. Handbook of Analysis and Quality Control of Fruit and Vegetable Products. Tata Mc Graw Hill Publishing Co., Calcutta. pp. 269-299.

Robinson, R.W. and Decker-Walters, D.S. 1999. Cucurbits CABI Publishing, CAB International, Wallingford Oxon OX10 8DE UK.

Selvi, N.A.T., Jansirani, P., Pugalendhi, L. and Nirmalakumari, A. 2012. Per se performance of genotypes and correlation analysis in Pumpkin (Cucurbita moschata Duch.ex Poir. Elec. J. Plant Breeding, 3(4): 987- 994

Seshadri, V.S. and More, T.A. 2009. Cucurbit Vegetable [Biology, Production and Utilization]. Studium Press (India) Pvt. Ltd. Delhi.

Sharma, S. and Ramana, R.T.V. 2013. Nutritional quality characteristics of pumpkin fruit as revealed by its biochemical analysis. Int. Food Res. J., 20(5): 2309-2316

Tian Cheng Rui, Li Yun, Cui Hong Wen and Cao Wei. 1999. Health-protection composition of pumpkin. Rep.Cucurbits Gent. Coop., 22: 59-60.

Weeden, N.F. 1984. Isozyme studies indicate that the genus Cucurbita is an ancient tetraploid. Report of the Cucurbit 
Genetics Cooperative, 7: 84-85.

Whitaker, T.W., Robinson, R.W. 1986.

Squash Breeding. In: Bassett MJ (Ed)

Breeding Vegetable Crops, AVI

Publishing Company, Westport,

Connecticut, USA, pp 209-242
Zinash, A., Workneh, T.S. and Woldetsadik, K. 2013. Effect of accessions on the chemical quality of fresh pumpkin. African J. Biotechnol., 12(51): 70927098.

\section{How to cite this article:}

Vimlesh Kumar, D.P. Mishra, G.C. Yadav and D.K. Dwivedi. 2017. Evaluation of F1 Hybrids / Genotypes of Pumpkin for Biochemical Traits. Int.J.Curr.Microbiol.App.Sci. 6(5): 982-989. doi: https://doi.org/10.20546/ijcmas.2017.605.108 